\title{
Keefektifan pendekatan saintifik berbasis scaffolding terhadap kerja ilmiah siswa Kelas XI pada materi alat optik
}

\author{
Sholeh Mawandi, Suci Prihatiningtyas, dan Novia Ayu Sekar Pertiwi \\ Universitas KH. A. Wahab Hasbullah \\ J1. Garuda No.09 Tambakberas Jombang \\ Surat-e: sholeh.mawandiII@gmail.com
}

Penelitian ini bertujuan untuk menuntaskan hasil belajar peserta didik setelah pembelajaran melalui pendekatan saintifik berbasis scaffolding pada kerja ilmiah peserta didik kelas XI pada materi alat optik. Rancangan pada penelitian ini menggunakan penelitian kuantitatif dengan pendekatan pra-eksperimen. Penelitian ini menggunakan model ujicoba One Group PretestPosttest Design. Subjek penelitian adalah peserta didik kelas XI IPA semester genap MA Darul 'Ulum Sumberpenganten Jogoroto Jombang pada tahun pelajaran 2017/2018. Hasil penelitian menunjukkan bahwa validitas perangkat pembelajaran dengan menggunakan pendekatan saintifik berbasis scaffolding pada materi alat optik meliputi RPP, LKS, dan THB berkategori baik dan layak untuk digunakan dalam pembelajaran. Keterlaksanaan pembelajaran yang menggunakan pendekatan saintifik berbasis scaffolding pada materi alat optik telah berjalan dengan baik sesuai dengan RPP yang dikembangkan. Aktivitas peserta didik selama pembelajaran menunjukkan kategori baik, hampir seluruh peserta didik aktif mengikuti kegiatan belajar mengajar. Hasil belajar siswa tuntas secara klasikal. Respons siswa terhadap pembelajaran memberikan respons positif. Kendala yang dijumpai selama pembelajaran berhubungan dengan kemampuan peserta didik dalam presentasi. Berdasarkan hasil penelitian di atas dapat disimpulkan bahwa pembelajaran melalui pendekatan saintifik berbasis Scaffolding terhadap kerja ilmiah peserta didik kelas XI pada materi alat optik efektif diterapkan di kelas dan dapat menuntaskan hasil belajar peserta didik.

The study aims to complete the learning outcomes of students after learning through a scientific approach based on Scaffolding on the scientific work of class XI students on optical equipment lesson. The design in this study uses quantitative research with a pre-experimental approach. This study uses the One Group Pretest-Posttest Design test model. Research subject was XI grade students of MA. Darul 'Ulum Sumberpenganten Jogoroto Jombang in academic year 2017/2018. The results showed that the validity of learning set using a scaffolding-based scientific approach to the material of optical devices including RPP, LKS, and THB was categorized as good and feasible to be used in learning. The implementation of learning that uses a scaffolding-based scientific approach on optical instrument material has gone well according to the developed RPP. The activities of students during learning show good categories, almost all students actively participate in teaching and learning activities. Student learning outcomes are complete classically. Students respond positively to learning process. Constraints encountered during learning relate to the ability of students in the presentation. Based on the findings above, it can be concluded that learning through the scientific approach based on Scaffolding on XI grade student's scientific work on the optical equipment lesson is effectively applied in the classroom and complete the learning outcomes of students.

Kata kunci: Pendekatan saintifik, Scaffolding, kerja ilmiah, alat optik, hasil belajar 


\section{Pendahuluan}

Pendidikan adalah aspek utama yang dibutuhkan dalam pengembangan kualitas kehidupan dan kemajuan sebuah negara. Pada abad 2I ini, negara-negara di dunia berlomba-lomba dalam meningkatkan kualitas pendidikan Sumber Daya Manusia (SDM) yang dimiliki berkualitas tinggi dan berdaya saing tinggi[I]. Pemerintah telah berupaya meningkatkan mutu pendidikan, salah satunya dengan mengoptimalkan pengembangan kurikulum 2013.

Pengembangan kurikulum 2013 sebaiknya mampu menjadi wadah pengembangan pendidikan berbasis kompetensi dan berbasis karakter [2]. Karakteristik kurikulum 2013 [3] yaitu: (I) peserta didik sebagai pusat utama dalam pembelajaran (student center); (2) peserta didik aktif dalam kegiatan pembelajaran; (3) peserta didik memperoleh pengalaman langsung dari kegiatan pembelajaran; (4) peserta didik dapat bersifat luwes dalam kegiatan pembelajaran; (5) dengan minat dan kebutuhan peserta didik dapat mempengaruhi hasil belajar mereka; (6) keterampilan berpikir kritis dapat terwujud; serta (7) peserta didik dapat menggunakan pendekatan ilmiah (pendekatan saintifik).

Pendekatan saintifik merupakan pendekatan pembelajaran yang disusun untuk mengaktifkan peserta didik dalam mengkonstruk pelajaran terkait dengan konsep materi, hukum atau prinsip yang terdapat dalam materi yang diajarkan. Tahapan dalam pendekatan saintifik yaitu: mengamati, merumuskan masalah, merumuskan hipotesis, mengumpulkan data, menganalisis data, menarik kesimpulan dan mengkomunikasikan konsep, hukum atau prinsip yang telah ditemukan [4].

Namun fakta di lapangan berbicara lain. Berdasarkan hasil wawancara kepada guru fisika yang dilaksanakan pada tanggal I6 Desember 2017 di MA.Darul 'Ulum Sumberpenganten, dapat diketahui bahwa implementasi Kurikulum 2013 di Madrasah tersebut khususnya di kelas XI mengalami banyak kendala, antara lain: (I) sistem penilaian sikap, pengetahuan, dan kerja ilmiah belum dapat dilaksanakan secara optimal; (2) pembelajaran belum memberikan pengalaman langsung kepada peserta didik; (3) pembelajaran belum menerapkan pendekatan ilmiah; (4) guru sebagai pusat dalam kegiatan pembelajaran; (5) materi pembelajaran yang dipahami peserta didik masih rendah.

Kurang optimalnya pelaksanaan Kurikulum 2013 di MA. Darul Ulum Sumberpenganten menyebabkan hasil belajar peserta didik rendah. Hal ini diketahui dari hasil belajar peserta didik kelas XI semester gasal, masih banyak peserta didik yang belum memenuhi kriteria ketuntasan minimum (KKM) secara klasikal yang telah ditetapkan sekolah yaitu $75 \%$. Permasalahan ini disebabkan selain pelaksanaan pembelajaran yang kurang optimal juga keterampilan kerja ilmiah peserta didik belum bisa dikembangkan dalam pembelajaran, sehingga dapat diketahui bahwa hasil dan proses pembelajaran di MA. Darul 'Ulum Sumberpenganten khususnya pada pembelajaran fisika masih menemui kendala. Hal tersebut tentu tidak diharapkan terus terjadi. Perlu dilakukan suatu upaya demi mewujudkan kualitas pembelajaran yang lebih baik serta sesuai dengan karakteristik Kurikulum 2013.

Dalam proses pembelajaran, pemilihan strategi pembelajaran harus dipertimbangkan dengan baik. Hal ini merupakan titik awal keberhasilan proses pembelajaran. Dalam penelitian ini, peneliti ingin mengimplementasikan pendekatan pembelajaran dan strategi pembelajaran yang sesuai dengan karakteristik Kurikulum 2013. Pendekatan dan strategi pembelajaran tersebut yaitu pendekatan saintifik melalui strategi pembelajaran Scaffolding.

Strategi pembelajaran Scaffolding adalah salah satu strategi pembelajaran yang menghubungkan pengetahuan awal peserta didik dengan pengetahuan baru yang akan diperoleh ketika pembelajaran. Vygostky menyatakan bahwa terdapat dua tingkatan perkembangan kemampuan anak yaitu, tingkatan kemampuan aktual (kemampuan awal yang dimiliki anak) dan tingkatan kemampuan potensial (kemampuan yang bisa dikuasai anak) [5]. Zona antara tingkat kemampuan aktual dan potensial dinamakan Zone of Proximal Development (ZPD).

Dalam strategi Scaffolding, guru memberikan motivasi kepada peserta didik untuk terlibat secara aktif dalam proses belajar. Guru membimbing atau membantu peserta didik pada awal pembelajaran. Bimbingan guru dilakukan secara bertahap agar proses pembelajaran atau tujuan yang hendak dicapai terlaksana dengan baik. Strategi pembelajaran Scaffolding yang disusun dalam penelitian ini memiliki beberapa ketentuan, dimana peserta didik menghubungkan pengetahuan yang telah diketahui sebelumnya dengan sesuatu yang baru akan diketahui dan peserta didik dituntut untuk belajar mandiri secara berkelompok dengan bantuan lembar kerja siswa (LKS).

Materi dalam LKS yaitu percobaan tentang Alat Optik. Dalam LKS tersebut peserta didik dapat membuktikan pembentukan bayangan pada Alat Optik khususnya analogi mata dan mikroskop melalui percobaan. Pada pembelajaran tentang materi Alat Optik tahun ajaran sebelumnya, guru menyuruh peserta didik untuk membaca sendiri buku pegangan peserta didik dan guru hanya mengajarkan rumus saja, tanpa menerapkan keterampilan kerja ilmiah untuk menemukan konsep sinar-sinar istimewa pada lensa dan pembentukan bayangan pada Alat Optik. Penggunaan LKS ini dimaksudkan untuk mendorong keaktifan peserta didik dalam proses belajar mengajar, peserta didik dapat memiliki keterampilan kerja ilmiah dan hasil belajar peserta didik tuntas secara individu dan klasikal.

Banyak dijumpai pembelajaran yang menggunakan pendekatan saintifik maupun strategi pembelajaran Scaffolding memberikan manfaat yang cukup besar bagi 
Keefektifan pendekatan saintifik berbasis scaffolding terhadap kerja ilmiah siswa Kelas XI pada materi alat optik

peserta didik. Penelitian terkait dengan pendekatan saintifik yang sudah pernah dilakukan sebelumnya yaitu penelitian [2] tentang implementasi pendekatan saintifik melalui Discovery Learning dalam peningkatan keterampilan berpikir kritis pembelajaran IPA di kelas IV SD. Sedangkan untuk penelitian terkait strategi pembelajaran Scaffolding yaitu penelitian [6] tentang pembelajaran fisika melalui pemrosesan top down berbasis Scaffolding untuk melatihkan keterampilan berpikir kritis.

Berdasarkan latar belakang di atas maka judul dalam penelitian ini adalah "Efektivitas Pendekatan Saintifik Berbasis Scaffolding Terhadap Kerja Ilmiah Peserta didik Kelas XI MA. Darul 'Ulum Sumberpenganten pada Materi Alat Optik”, dengan pertimbangan sebagai berikut:

I. pembelajaran dengan menggunakan pendekatan saintifik berbasis Scaffolding belum diterapkan di sekolah tersebut, khususnya untuk mata pelajaran fisika pada pokok bahasan Alat Optik.

2. kolaborasi antara pendekatan saintifik dengan strategi pembelajaran Scaffolding yang belum dilakukan sebelumnya di sekolah tersebut diyakini dapat mengajarkan keterampilan kerja ilmiah dan menuntaskan hasil belajar peserta didik.

\section{Kajian Pustaka}

\section{Pendekatan Saintifik}

Pendekatan saintifik dikembangkan melalui ilmu pendidikan Amerika pada akhir abad ke 19. Pendekatan saintifik mengajarkan pada peserta didik tentang pencarian fakta-fakta ilmiah dalam kegiatan laboratorium [7]. Pendekatan saintifik mengajarkan peserta didik untuk merumuskan masalah dan hipotesis, peduli terhadap lingkungan, memiliki keinginan untuk mengetahui ilmu dan keinginan untuk gemar membaca [8]. Dalam pelaksanaan pendekatan saintifik, peserta didik akan melakukan penyelidikan, menemukan, mengembangkan hasil karya yang mereka hasilkan dan menyajikan hasil karya yang mereka temukan.

Pendekatan saintifik merupakan pendekatan pembelajaran yang disusun untuk mengaktifkan peserta didik dalam mengkonstruk pelajaran terkait dengan konsep materi, hukum atau prinsip yang terdapat dalam materi yang diajarkan. Tahapan pendekatan saintifik antara lain mengamati, merumuskan masalah, merumuskan hipotesis, mengumpulkan data, menganalisis data, menarik kesimpulan dan mengkomunikasikan [4]. Pendekatan saintifik berperan penting dalam proses pembelajaran berbasis kontekstual [9].

Dari beberapa pendapat para ahli dapat ditarik kesimpulan bahwa pendekatan saintifik merupakan pendekatan yang mengharuskan peserta didik untuk mencari tahu fakta-fakta dan pengetahuan yang sesuai dengan materi yang diajarkan yang diintegrasikan dengan keterampilan kerja ilmiah.

Karakteristik terkait pendekatan saintifik dalam pembelajaran adalah sebagai berikut:

I. peserta didik sebagai pusat dalam pembelajaran.

2. keterampilan proses sains digunakan untuk mengajarkan penerapan konsep kepada peserta didik

3. proses-proses kognitif dilibatkan untuk merangsang perkembangan keterampilan berpikir tingkat tinggi peserta didik.

4. karakter peserta didik dikembangkan dalam kegiatan pembelajaran.

Langkah-langkah pendekatan saintifik sebagai berikut [3]:

I. Mengamati, yaitu kegiatan peserta didik dengan cara mengoptimalkan panca indera, misalnya kegiatan mengamati percobaan menggunakan alat bantu maupun tanpa alat bantu. Hasil dari kegiatan ini peserta didik dapat mengidentifikasi masalah.

2. Menanya, yaitu kegiatan peserta didik mengungkapkan rasa ingin tahu mereka mengenai suatu peristiwa. Hasil kegiatan ini peserta didik mampu merumuskan masalah dan merumuskan hipotesis.

3. Mengumpulkan data, yaitu kegiatan peserta didik mencari informasi sebagai bahan untuk dianalisis dan disimpulkan. Hasil kegiatan ini, peserta didik dapat menguji hipotesis.

4. Mengasosiasi, yaitu kegiatan peserta didik mengolah data hasil percobaan. Hasil kegiatan ini peserta didik dapat menyimpulkan hasil percobaan.

5. Mengomunikasikan, yaitu kegiatan peserta didik menyampaikan hasil percobaan. Hasil kegiatan ini peserta didik dapat mempertanggungjawabkan apa yang mereka peroleh dari hasil percobaan.

Teori belajar yang relevan dengan pendekatan saintifik yaitu teori Bruner, teori Piaget, dan teori Vygotsky. Teori belajar Bruner [IO] merupakan teori belajar penemuan peserta didik belajar dan mengembangkan apa yang dipikirkan jika mereka memikirkannya, peserta didik akan memperoleh kepuasan jika mereka memperoleh penghargaan, dengan kegiatan penemuan peserta didik mempelajari teknik-teknik penemuan, penemuan akan memperkuat retensi ingatan peserta didik. Teori Bruner sesuai dengan pendekatan saintifik.

Teori Piaget adalah teori yang berhubungan dengan pembentukan dan perkembangan skema (jamak skemata). Skema adalah struktur mental atau struktur kognitif yang membuat seseorang secara intlektual maupun beradaptasi dan mengkordinasi lingkungan sekitar [II]. Skema terus berkembang, dari anak berkembang menjadi dewasa. Proses perubahan schemata anak menjadi dewasa disebut 
Keefektifan pendekatan saintifik berbasis scaffolding terhadap kerja ilmiah siswa Kelas XI pada materi alat optik

adaptasi. Adaptasi terbentuk dengan cara yaitu asimilasi dan akomodasi. Asimilasi adalah proses pemahaman tentang pengalaman baru dari skema. Sedangkan akomodasi adalah proses perubahan skema agar sesuai dengan situasi yang sekarang.

Teori Vygotsky adalah teori yang mengajarkan peserta didik menyelesaikan tugas yang belum pernah diajarkan sebelumnya tetapi tugas tersebut masih dalam zona kemampuan mereka. Zona ini dinamakan Zone of Proximal Development (ZPD). ZPD adalah kemampuan siswa dalam menyelesaikan masalah dengan bantuan orang dewasa atau sesama teman yang dianggap mampu sehingga mereka memahami apa yang telah mereka peroleh, atau temukan [I2].

\section{Strategi Pembelajaran Scaffolding}

Menurut Bruner, seorang ahli psikologi perkembangan kognitif masa lalu, mengemukakan strategi pembelajaran yang dikenal dengan istilah Scaffolding. Scaffolding yaitu tahapan yang dilakukan oleh orang dewasa untuk membimbing anak-anak melalui zona perkembangan proksimal. Strategi Scaffolding sesuai dengan konsep Vygotsky tentang pembelajaran dengan bantuan (assisted learning). Assisted learning yaitu strategi mengajar ysng memandu peserta didik agar dapat menguasai keterampilan yang diperoleh secara tuntas dan dapat meningkatkan kemampuan kognitif [I2].

Pada pembelajaran Scaffolding, pada tahap awal pembelajaran guru memberikan bantuan kepada peserta didik, kemudian guru mengurangi bantuan tersebut secara bertahap. Guru memberikan kesempatan peserta didik untuk mengerjakan sendiri dan mengambil alih tangung jawab pelajaran tersebut. Bantuan yang diberikan guru dapat berupa petunjuk, peringatan, dorongan, mengajarkan penyelesaian masalah secara bertahap kedalam bentuk lain yang memungkinkan peserta didik dapat mandiri.

Tahapan strategi pembelajaran Scaffolding sebagai berikut:

I. Assemen kemampuan dan tahap perkembangan setiap peserta didik dalam Zone of Proximal Development (ZPD).

2. Menjabarkan tugas dengan penyelesaian masalah secara bertahap dan rinci

3. Pemberian tugas belajar disesuaikan dengan tahap perkembangan peserta didik.

4. Mendorong peserta didik untuk menyelesaikan tugas belajar secara mandiri.

5. Memberikan bantuan dalam bentuk pemberian isyarat, kata kunci, tanda mata (minders), dorongan, contoh atau hal lain yang dapat memancing peserta didik untuk mandiri dalam belajar.

\section{Keterampilan Kerja IImiah}

Kompetensi peserta didik dalam pembelajaran fisika ditekankan dengan pemberian pengalaman langsung. Kemampuan peserta didik dalam melakukan strategi ilmiah dan kerja ilmiah dapat ditingkatkan dengan pemberian pengalaman langsung. Pengalaman langsung mengarahkan peserta didik untuk bersikap positif dan kerja ilmiah peserta didik terhadap pembelajaran fisika [I3]. Keterampilan kerja ilmiah terdiri dari keterampilan hands-on (keterampilan tangan) dan minds-on (keterampilan berpikir). Kedua keterampilan ini tidak datang secara otomatis tetapi perlu dilatihankan kepada peserta didik.

Keterampilan kerja ilmiah merupakan kegiatan yang menciptakan karya terkait dengan ilmu pengetahuan dan memberikan penjelasan berdasarkan fakta ilmiah [I4]. Keterampilan kerja ilmiah yang dikembangkan dalam penelitian ini meliputi mendefinisikan masalah, menyatakan hipotesis, merancang percobaan, mengumpulkan dan menganalisis data, mengevaluasi atau menyampaikan hasil percobaan, dan menyimpulkan [I5].

Keterampilan kerja ilmiah harus ditumbuhkan sesuai dengan taraf perkembangan pemikiran peserta didik. Keterampilan kerja ilmiah sebagai penggerak penemuan, pengembangan, pertumbuhan dan perkembangan sikap, wawasan dan nilai. Keterampilan kerja ilmiah yang dipadukan dengan kegiatan pra-eksperimen diharapkan peserta didik dapat mempelajari fisika dengan pengamatan langsung, dapat melatih berpikir ilmiah, dapat menanamkan dan mengembangkan sikap ilmah, serta dapat menemukan dan memecahkan berbagai masalah baru melalui metode ilmiah. Selain itu kegiatan praeksperimen dapat membantu pemahaman peserta didik terhadap pelajaran menjadi lebih bermakna dan mendalam.

\section{Metode Penelitian}

Subjek ujicoba adalah peserta didik kelas XI IPA MA. Darul 'Ulum Sumberpenganten. Penelitian ini dilaksanakan pada semester genap tahun ajaran 2017/2018. Metode penelitian destriptif kuantitatif dengan pendekatan Pre-Experimental. Rancangan penelitian one group pretest-posttest design dengan pola:

\section{$\mathrm{O}_{1} \mathrm{X} \mathrm{O}_{2}$}

Keterangan:

O I adalah tesawal (pretest) untuk mengetahui penguasaan peserta didik terhadap materi pelajaran sebelum pembelajaran berlangsung.

$\mathrm{X}$ adalah perlakuan pembelajaran dengan menerapkan perangkat pembelajaran dengan pendekatan saintifik berbasis Scaffolding 
$\mathrm{O}_{2}$ adalah tes akhir (posttest) untuk mengetahui penguasaan peserta didik terhadap materi pelajaran setelah pembelajaran berlangsung.

Instrumen penelitian yang digunakan adalah lembar rencana pelaksanaan pembelajaran (RPP), lembar aktivitas peserta didik, angket respon peserta didik, lembar tes hasil belajar dan lembar kendala dalam pembelajaran.

\section{Hasil Penelitian dan Pembahasan}

Berdasarkan hasil penelitian didapatkan bahwa:

\section{Keterlaksanaan rencana pembelajaran (RPP) \\ pelaksanaan}

Kegiatan pembelajaran yang tercantum pada RPP terdiri dari kegiatan pendahuluan, kegiatan inti, dan kegiatan penutup.

a) Kegiatan pendahuluan sangat penting untuk menarik perhatian peserta didik. Pada kegiatan pendahuluan termasuk kategori baik dengan nilai dari pengamat rata-rata antara 3,67 s.d. 4,0. Hal ini berarti guru sudah mampu membuka kegiatan pembelajaran dengan baik, guru mampu memotivasi peserta didik, mengaitkan pengetahuan awal yang dimiliki peserta didik, dan menyampaikan tujuan pembelajaran sehingga peserta didik mengerti dan memahami dengan apa yang akan mereka pelajari

b) Pada kegiatan inti, guru mampu menyajikan informasi dan mendemonstrasikan pengetahuan atau keterampilan, mengorganisasikan peserta didik dalam kelompok-kelompok belajar, membimbing kelompok bekerja dan belajar, mengajarkan pendekatan saintifik, membantu peserta didik saat mengalami kesulitan, mengarahkan diskusi, menyelenggarakan diskusi, melakukan percobaan termasuk kategori baik.

c) Pada kegiatan penutup, termasuk kategori baik karena nilai pengamat 4,0. Guru mampu membimbing dan mengarahkan peserta didik dalam membuat kesimpulan dan guru memberikan penghargaan kepada kelompok yang hasil kerjanya baik, sehingga peserta didik termotivasi untuk pembelajaran selanjutnya.

\section{Aktivitas peserta didik}

Persentase aktivitas peserta didik pada masing-masing pertemuan dapat dilihat pada Gambar I.

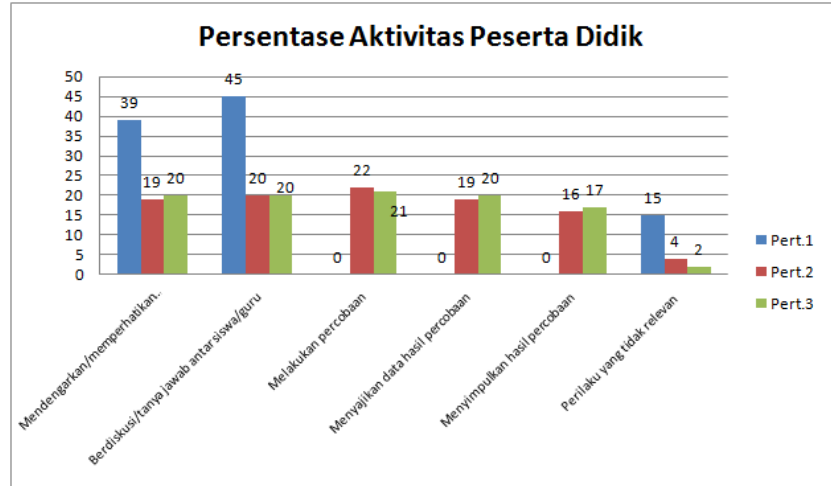

Gambar I. Diagram aktivitas peserta didik dalam pembelajaran di kelas

Berdasarkan gambar I di atas untuk kegiatan mendengarkan/memperhatikan penjelasan guru, peserta didik sangat antusias hal ini terlihat bahwa persentase yang diperoleh 39\%. Pada pertemuan ke 2 menurun menjadi $19 \%$ hal ini disebabkan peserta didik kebingungan dengan yang disampaikan oleh guru sehingga mereka gaduh. Setelah mendapatkan penjelasan dari guru, pada pertemuan 3 peserta didik mulai aktif mendengarkan dengan persentase $20 \%$.

Kegiatan diskusi pada pertemuan pertama dengan persentase $45 \%$ kemudian menurun pada pertemuan 2 dan 3. Hal ini disebabkan pada pertemuan I, peserta didik turut mendiskusikan soal yang diberikan oleh guru lalu mendiskusikan untuk mencari jawaban secara bersama-sama dengan cara membaca buku pegangan peserta didik. Sedangkan untuk pertemuan 2 dan 3 saat percobaan dilakukan pembagian tugas terkait pengerjaan LKS dalam kelompok sehingga mereka cenderung mengerjakan tugas mereka sendiri.

Penyajian data hasil percobaan untuk pertemuan I tidak dilakukan karena pertemuan I hanya mendiskusikan materi bukan percobaan. Kegiatan percobaan dilakukan di pertemuan 2 dan 3. Untuk pertemuan 2, peserta didik masih malu-malu dalam menyampaikan data hasil percobaan di depan kelas sehingga persentasenya I9\%. Setelah bimbingan dan bantuan dari guru akhirnya pertemuan 3 mereka sudah mulai berani dalam menyampaikan data hasil percobaan sehingga persentasenya meningkat menjadi $20 \%$. Hal ini sama seperti dalam kegiatan menyimpulkan hasil percobaan.

Selama pembelajaran pertemuan I banyak perilaku siswa yang tidak relevan yaitu mereka gaduh saat melakukan diskusi untuk mencari jawaban soal diskusi. Mereka lebih banyak bercerita dengan temannya dibandingkan membaca buku pegangan siswa, sehingga persentase perilaku tidak relevan pada pertemuan ini I5\%. Setelah mendapatkan bimbingan dari guru, perilaku tidak relevan mulai berkurang untuk pertemuan 2 dan 3 yaitu $4 \%$ dan $2 \%$. 


\section{Tes hasil belajar}

Tes dilakukan untuk mengetahui kemampuan dan pemahaman peserta didik dalam mencapai tujuan pembelajaran. Pada penelitian ini dilakukan tes awal (pretes) dan tes akhir (posttes). Di MA Darul 'Ulum Sumberpenganten Jogoroto, peserta didik dikatakan tuntas secara individu jika proporsi jawaban benar peserta didik $\geq 72 \%$. Untuk lebih jelas tentang ketuntasan hasil belajar peserta didik dapat dilihat pada gambar 2 .

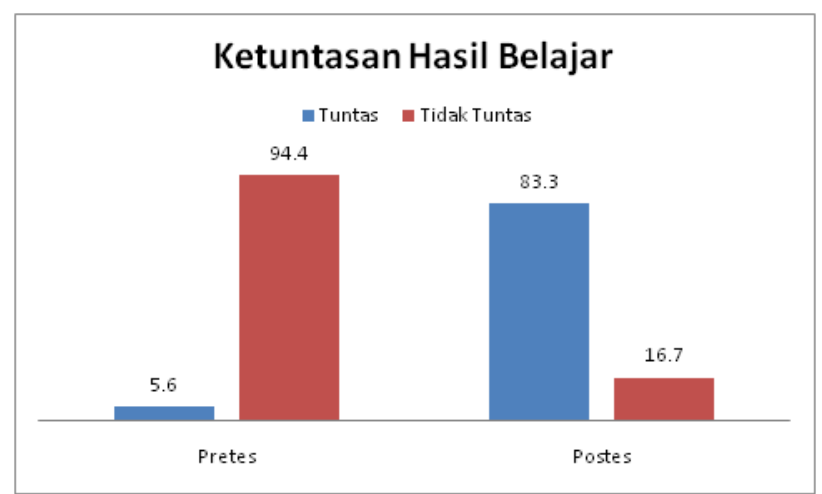

Gambar 2. Diagram Ketuntasan Hasil Belajar Peserta Didik

Berdasarkan gambar 2 di atas, pada saat pretes nilai yang diperoleh peserta didik kurang dari 72 , hanya terdapat I peserta didik yang memiliki nilai di atas KKM yaitu $74, \mathrm{I}$. Hal ini dikarenakan sebelum pembelajaran peserta didik tidak memahami materi yang diujikan sehingga nilai yang mereka peroleh kurang dari KKM yaitu sebesar 72 . Setelah diadakan pembelajaran dengan menggunakan pendekatan saintifik berbasis scaffolding dan dilakukan posttes, $83,3 \%$ peserta didik tuntas secara klasikal. Namun ketika ditinjau berdasarkan ketuntasan individu terdapat 3 peserta didik yang tidak tuntas. Beberapa peserta didik yang tidak tuntas disebabkan karena dari IO soal yang diujikan, kesalahan mereka ketika menjawab soal yang memiliki ranah kognitif menganalisis (C4). Hal ini diperkirakan mereka belum memahami ranah kognitif yang dimaksud. Peserta didik yang tidak tuntas diberikan remidi berupa tugas yang terdapat di buku pegangan siswa.

\section{Respon peserta didik}

Respon peserta didik terhadap komponen keterbaruan. Peserta didik merasa ada hal yang baru dengan LKS, percobaan KIT optik, suasana belajar dan cara guru mengajar. Penyebabnya pembelajaran selama ini peserta didik diajarkan materi saja, tanpa diajarkan percobaan. Alat percobaan tertata rapi di laboraturium dan tidak pernah digunakan dalam pembelajaran. Semua komponen terkait materi yang disampaikan guru, contoh-contoh soal, LKS, cara mengajar guru sangat mudah diterima oleh peserta didik. Hal ini sangat berpengaruh terhadap hasil belajar peserta didik. Pendekatan saintifik berbasis scaffolding yang diajarkan kepada peserta didik merupakan hal yang baru bagi mereka. Komponenkomponen terkait tentang keterampilan kerja ilmiah melalui pendekatan saintifik berbasis scaffolding yaitu cara menggunakan KIT optik, merumuskan masalah, merumuskan hipotesis, menentukan variable percobaan, melakukan percobaan, menganalisis percobaan dan menyimpulkan hasil percobaan. Dari semua komponen tersebut mereka merasa baru, karena sebelumnya belum pernah diajarkan komponen-komponen seperti itu.

Pemberian bantuan dan bimbingan oleh guru membuat peserta didik sangat mudah dalam mempelajari keterampilan kerja ilmiah yang terdapat dalam LKS. Peserta didik berminat jika mengikuti pembelajaran menggunakan pendekatan saintific berbasis scaffolding untuk materi pembelajaran yang lain karena mereka merasa penjelasan guru saat mengajar jelas, bimbingan dan pemberian bantuan saat mengerjakan LKS sangat jelas. Hal ini menyebabkan peserta didik mudah dalai menjawab butir soal dan merasa baru dengan butir soal yang diberikan.

Secara keseluruhan, respons positif diberikan peserta didik terhadap pembelajaran. Hal ini menunjukkan bahwa peserta didik antusias pada pembelajaran yang disajikan.

\section{Kendala yang dihadapi}

Kendala yang dijumpai selama KBM, Peserta didik belum terbiasa dengan pembelajaran percobaan menggunakan KIT sederhana dengan pendekatan saintifik berbasis scaffolding sehingga guru memerlukan waktu yang lama untuk menjelaskan langkah-langkah percobaan menggunakan KIT optik, presentasi peserta didik cenderung monoton dan kurang siap, antara kelompok penyaji dengan kelompok yang menanggapi/mengajukan pertanyaan kurang siap, sehingga lebih banyak kelompok yang diam dan tidak bertanya/menanggapi presentasi kelompok yang maju, dan Ditemukan beberapa peserta didik yang menunjukkan perilaku yang tidak relevan, belum menunjukkan karakter keterampilan sosial yaitu menjadi pendengar yang baik.

\section{Kesimpulan}

Pembelajaran melalui pendekatan saintifik berbasis Scaffolding terhadap kerja ilmiah peserta didik kelas XI pada materi alat optik efektif diterapkan di kelas dan dapat menuntaskan hasil belajar peserta didik.

\section{Ucapan Terimakasih}

Ucapan terimakasih ditujukan kepada Allah SWT yang memberikan rahmat serta hidayahnya sehingga penelitian 
ini dapat terselesaikan tepat waktu. Ucapan terimakasih juga disampaikan kepada seluruh dosen Pendidikan Fisika Fakultas Ilmu Pendidikan Universitas KH. A. Wahab Hasbullah, kepala sekolah dan guru MA. Darul 'Ulum Sumberpenganten yang telah turut serta dalam keterlaksanaan kegiatan penelitian ini. Ucapan terimakasih disampaikan kepada pihak-pihak yang telah mendukung pelaksanaan penelitian.

\section{Kepustakaan}

[I] Jaya Gede Wiratma, dkk, Penerapan Pendekatan Saintifik Melalui Metode Eksperimen Pada Pembelajaran Fisika Siswa Kelas X MIA 3 SMA Negeri I Tenggarong (Materi Suhu Dan Kalor), Saintifika. Volume16, Nomor 2, Desember 20I4, hlm. $22-29$

[2] Nur Luthfi Rizqa Herianingtyas, dkk, Implementasi Pendekatan Saintifik Melalui Discovery Learning Dalam Peningkatan Keterampilan Berpikir Kritis Pembelajaran IPA Di Kelas IV SD, 20I4. hlm. I - 6

[3] Kemendikbud, Materi Pelatihan Guru Implementasi Kurikulum 2013 Tahun 2014 SD Kelas IV., Jakarta: Depdiknas, 2014.

[4] Zykra Zakiah, Pendekatan Pembelajaran Saintifik Terhadap Hasil Belajar Ilmu Pengetahuan Alam (IPA) Pada Anak Tunanetra Kelas I. Skripsi. Pendidikan Luar Biasa, FIP, UNESA, 2015

[5] Udin Sidik Sidin, Penerapan Strategi Scaffolding Pada Pembelajaran Pemrograman Web Di SMK Kartika Wirabuana I, Jurnal Publikasi Pendidikan, Volume VI No 3 Oktober 2016

[6] Muhammad Aqil Rusli, dkk, Pembelajaran Fisika Melalui Pemrosesan Top Down Berbasis Scaffolding Untuk Melatihkan Keterampilan Berpikir Kritis, Jurnal Sainsmat, Vol. III, No. I, Maret 20I4, Halaman I-II

[7] Maria Emanuela Ine, Penerapan Pendekatan Scientific Untuk Meningkatkan Prestasi Belajar Siswa Pada Mata Pelajaran Ekonomi Pokok Bahasan Pasar, Prosiding Seminar Nasional 9 Mei 2015 .

[8] A Machin, Implementasi Pendekatan Saintifik, Penanaman Karakter Dan Konservasi Pada Pembelajaran Materi Pertumbuhan, JPII 3 (I) (20I4) 28-35

[9] Irwandi, Pengaruh Pendekatan Kontekstual dalam Pembelajaran Biologi melalui Strategi Inkuiri dan Masyarakat Belajar pada Siswa dengan Kemampuan Awal Berbeda terhadap Hasil Belajar Kognitif di SMA Negeri Kota Bengkulu, Jurnal Kependidikan Triadik, Volume I2, No. I, April 2009

[I0] Carin, A.A. \& Sund, R.B, Teaching Science trough Discovery, $3^{r d}$ Ed. Columbus: Charles E. Merrill Publishing Company, 1975.

[II] Baldwin, A.L, Theories of Child Development. New York: John Wiley \& Sons, 1967.

[12] Nur, M. \& Wikandari, P.R, Pengajaran Berpusat Kepada Siswa Dan Pendekatan Konstruktivis Dalam Pengajaran. Surabaya: Universitas Negeri Surabaya University Press, 2000.

[13] Sudi Dul Aji, Dkk, Dampak PBL Terhadap Kerja Ilmiah Mahasiswa Pada Perkuliahan Pengembangan Media Pembelajaran,Jurnal Inspiraasi Pendidikan.
Keefektifan pendekatan saintifik berbasis scaffolding terhadap kerja ilmiah siswa Kelas XI pada materi alat optik

[I4] Carl J. Wenning, Assessing Inquiry Skill as a Component Of Scientific Literacy, J. Phys. Tchr. Educ. Online, 4(2), Winter 2007

[15] Anna Karelina and Eugenia Etkina, Acting like a physicist: Student approach study to experimental design, PHYS. REV. ST PHYS. EDUC. RES. 3, 020106 !2007" 